Article

\title{
Innovative Infrastructure Fund to Ensure the Financial Sustainability of PPP Projects: The Case of Chile
}

\author{
Patricio Mansilla * and José Manuel Vassallo \\ Department of Transportation Engineering, Urban and Regional Planning, Escuela de Caminos, \\ Canales y Puertos, Universidad Politécnica de Madrid, 28040 Madrid, Spain; josemanuel.vassallo@upm.es \\ * Correspondence: pmansill@hotmail.com or patricio.mansillac@alumnos.upm.es
}

Received: 28 October 2020; Accepted: 26 November 2020; Published: 28 November 2020

\begin{abstract}
Recently, the Chilean government created the Chilean Infrastructure Fund (CIF) that will allow taking advantage of the value of existing infrastructure assets. The fund will enable the government to finance new infrastructure projects with the resources obtained from new concessionaires' payments to the government for the value of retendering existing public-private partnership (PPP) projects. The purpose of this paper is to evaluate the contribution that this new public institution will bring to the financial sustainability of infrastructure in Chile, the opportunities and challenges for its implementation, and its economic value. The research has a qualitative and quantitative approach. Based on the understanding of the new concept of asset recycling, the application of economic foundations, and financial methodologies such as discounted cash flows and real options, the research assessed the institutional and economic value of the new Chilean Infrastructure Fund. The main findings are that the new Chilean Infrastructure Fund will create public value and public wealth since it will foster good governance, streamline the concession system, accelerate the implementation of sustainable PPP projects, and improve planning schemes among others. Other countries could follow this experience, promoting infrastructure funds to improve governance and accelerate the implementation of sustainable PPP projects.
\end{abstract}

Keywords: asset recycling; economic infrastructure; public value; public wealth; public-private partnership (PPP); real options; social infrastructure; sustainability; transportation; valuation

\section{Introduction}

The concession system for infrastructure projects in Chile will soon turn 25 years old. According to the Chilean concession law, the concession (a type of public-private partnership (PPP)) includes the provision, in the concession area, of services for which the works was built; maintenance of the works in optimum operational conditions; charge of rates that will be paid by the users of the services investment; and reinvestments comprising the project's development plan [1].

According to official data from the Chilean Ministry of Public Works (MOP for its Spanish acronym), Chile has 94 concession projects ( 47 highways, 23 airports, 8 hospitals and prisons, and 16 cross-sector projects) and an investment amount of around US\$22,151 million [2].

The success that Chile has had in the implementation of the concession system is confirmed by Infrascope/The Economist Intelligence Unit (2019), which is an index about the capacity of countries to do PPPs. Chile is again classified as the leader in Latin America in the use of public-private partnerships (PPP), considering regulations, institutions, maturity, investment climate, and financing [3]. In this regard, PPP projects in Chile have had an adequately competitive level. According to the MOP, $68 \%$ of the projects have received three or more offers and $24 \%$ of the projects have received between two and three offers [4]. 
The success is also explained by the institutional soundness and allocation of financial resources to feasibility studies that facilitate the determination of investment, operation and maintenance costs, and rates of return. Chile allocates around US $\$ 70$ million a year to feasibility studies and supervision, and around US\$15 million a year to pay the staff of the Chilean Concession Department (DGC for its Spanish acronym) [4].

Currently, Chile has a concession plan with total investments of US\$14,884 million for the period 2019-2023, including 24 highways for US\$9924 million, 18 hospitals for US\$2618 million, 5 trams and cable cars for US $\$ 890$ million, 2 dams for US\$823 million, 7 airports for US\$504 million, and 4 cross-sector projects for US $\$ 125$ million.

Due to the ambitious Chilean concession plan, a state-owned corporation, the Chilean Infrastructure Fund (CIF), has recently been created to prepare biddings terms for PPP projects, finance or invest in infrastructure projects, and provide guarantees or loans. The CIF will ensure financial sustainability of the concession system in Chile because in the long run it will have resources and financial tools to finance infrastructure projects. The fund will also be responsible for tendering financially sustainable PPP projects. According to Turley and Semple (2013) of the International Institute for Sustainable Development, the concept of financial sustainability of PPP projects refers to the ability of those projects to "repay interest and principal to commercial lenders and produce acceptable dividends to owners" [5].

The CIF will tender existing infrastructure assets (brownfield projects) that can generate revenues for the concessionaire. Bidders will compete to win the concessions offering the highest payment to the CIF for managing and operating the existing infrastructure. The CIF can use those payments to finance new infrastructure. Therefore, the CIF will be able to ensure funding not just for the current generation, but also for future ones.

The recycling of infrastructure assets allows the state to create value based on existing infrastructure through private or public-private participation. The government generates revenue when leasing or through concessions of existing assets, and those resources allow financing the new infrastructure investments (Nowacki et al., 2016) [6]. The most relevant experience is in Australia.

According to the Australian Government's Treasury (2019), asset recycling is included in its public policy through the National Partnership Agreement on Asset Recycling (NPA) [7]. This agreement was created in 2014 by the Council of Australian Governments (COAG) to reduce the financing limitations of the states and territories in order to increase investment in productive infrastructure and economic growth, promoting the sale of state property, supporting with financial liquidity, and recycling the capital in additional infrastructure. In Australia, there was a pre-NPA experience through the Restart New South Wales Fund which was set up for asset recycling in 2011, and started projects in 2013 (Nowacki et al., 2016) [6].

In Australia, asset recycling involves the monetization of existing public assets through sale or lease to the private sector and the reinvestment of those resources in new infrastructure that may be managed either through concession or conventional means. The advantage of asset recycling is that it does not increase public debt and maintains, or potentially improves, the level of service and maintenance of existing infrastructure. More detail on the asset recycling stages can be found in Casady and Geddes (2020) [8].

Nowacki et al. [6], established that, in general, the success of asset recycling always requires state support in cases where projects are not self-financing In those cases, subsidies must be used, which are ultimately paid via taxes. Recycling asset management by itself does not guarantee that a new project will be financed throughout its life cycle.

The innovative aspect of the CIF is that the capital contributions to create the fund would include national state-owned assets for public use. These assets may be valued through the option of the fund to have projects included in its project portfolio. In practice, the fund may collect resources based on the residual values of concession projects that have been previously tendered by the MOP. 
The residual value of each concession project to be included in the fund will depend on an appropriate estimate of future cash flows, including the demand, revenues, and operating and maintenance costs of the infrastructure. This present value of the residual value of a concession will make it possible to generate revenues for the fund to be used in a new bidding process either for the same or for another project. One of the objectives of the fund is to generate annual profits from the activities under its management.

The purpose of this paper is to study the consequences of the Chilean Infrastructure Fund (CIF), focusing on answering the questions about its strengths and weaknesses, its public value for the country, and how it would achieve good governance in its implementation. In addition, through a preliminary valuation of the fund, this study estimates the capacity of the fund to create public wealth. Thus, the main conclusions are that the CIF will create public value and public wealth, but it is recommended that the CIF does not participate as a shareholder of the projects that are tendered by concession. The research also recommends the creation of an independent regulatory body for public-private partnerships to ensure that the decisions are sustainable from the economic point of view.

This paper is organized as follows: in the second section, the Chilean concession system is explained. Third, the governance of the Chilean Infrastructure Fund is covered. Fourth, the creation of public wealth and public value concepts are reviewed. Fifth, the research methodologies used in the case study are explained. Sixth, findings and discussion from the study are reported. The last section includes conclusions and suggestions for further research.

\section{A Brief Description of the Chilean Concession System}

The Chilean Concession Department (DGC for its Spanish acronym) of the MOP is responsible for the whole life-cycle of a concession project, including the preparation of feasibility studies in engineering, environmental, financial, and economic areas. Once the feasibility of a project has been checked, the DGC drafts the concession contract. Subsequently, and after approval of the contract by the Chilean Ministry of Finance and the Office of the Comptroller General of the Republic, the DGC calls for bids for the project to make sure that the tender is transparent and competitive. Once the concession is awarded, the DGC oversees the construction and operation phases of the concession for the term of the concession contract.

The experience of the DGC is very important and Chile has transformed its infrastructure, especially in the sectors of urban and interurban roads, airport, public buildings, and urban equipment.

The MOP has the responsibility to tender roads and some public buildings. Additionally, the MOP through a legal provision called the mandate agreement, receives the order from the public agency responsible for other types of infrastructure. The MOP then carries out the tender and subsequent joint supervision of the project. Institutions that have signed the mandate agreement are the Chilean Department of Civil Aeronautics (DGAC for its Spanish acronym) in the case of airports and the Chilean Ministry of Public Health for hospitals, among others.

The success of the Chilean concessions system has not been without challenges. In this regard, some of the difficulties that the MOP (2016) have encountered at the organizational level are [4]:

- Mitigating staff turnover; specialized personnel in concessions have a market value that makes their retention difficult;

- Investing permanently in the enhancement of information systems to improve management and traceability of the background of each project to increase efficiency in the processes; and

- Improving internal processes and risks associated with the responsibilities and roles of each unit.

Chile has had an appropriate use of economic bidding mechanisms (Gomez-Lobo and Hinojosa, 2000), such as higher payment to the state for pre-existing infrastructure, lower state contribution, and least present value of revenues, among others, choosing the most convenient in each project to generate high competition in most of the bids [9]. 
The DGC has implemented the minimum revenue guarantee (MRG) which allows the concessionaire to receive a payment from the state when the annual revenue is lower than the minimum revenue guaranteed established by the state in the concession contract. In this case, the state pays the difference between the annual collection and the minimum revenue guarantee (Vassallo and Sánchez, 2006) [10].

Some of the difficulties in the implementation of the concession system in Chile, according to CAF-Banco de Desarrollo de América Latina (2018), relate to the need to amend concession contracts, including: unforeseen improvements to the infrastructure with respect to the original project, additional works not provided for in the contract, changes in tariffs or contractual requirements, and changes in the schedule of work or in the commissioning dates [11].

Despite the fact that Chile has not had a specific agency or a particular public policy for the development of the asset recycling mechanism, the MOP together with the Chilean Ministry of Finance have indirectly applied the concept of asset recycling through the use of the bidding variable payment to the State, it is generated by existing infrastructure used in various concession projects that have allowed for the continued financing of new infrastructure or expansions of existing infrastructure. The funds collected in the concessions were considered general funds of the nation and used by the Ministry of Finance. Chile did not have a specific fund when it designed the first set of asset recycling projects.

The DGC has used network schemes concurrently with intergenerational self-financing schemes. In the first case, Route 5 highway from La Serena to Puerto Montt with a length of about $1200 \mathrm{~km}$ was divided into eight sections.

In the Chilean case, recycled assets have a mandatory maintenance plan and service regulations according to the concession contracts. These provisions have to be complied with by the concessionaire throughout the concession period. Maintenance programs must be implemented rigorously by concessionaires, thereby ensuring that the adequate maintenance will extend over the lifespan of the assets and making infrastructure maintenance more sustainable.

Some of the most important civil works of interurban road concessions in Chile are: double lanes with two tracks each, links, bridges, new roads parallel to the main highway, pedestrian walkways for east-west traffic of the population, passages of livestock and agricultural machinery where necessary, and areas of police control and Agricultural and Livestock Service.

Some of the performance indicators for highway maintenance implemented in road concessions in Chile are:

- Maximum international roughness index (IRI) $3.5 \mathrm{~m} / \mathrm{km}$. This will be obtained from measurements made for each runway and by homogeneous sectors of $200 \mathrm{~m}$.

- Inspection control of high severity cracks that cause structural damage to the pavements.

- No open potholes.

- Slip resistance coefficient of friction between 0.40 and 0.55 .

- Berms: open potholes will not be allowed on the berms or descents greater than $1 \mathrm{~cm}$. Among the latter, the joint between the rolling surface and the berm is considered.

Routine maintenance will be carried out at least once a year and will include at least the following activities: rubbing, clearing and cleaning of the strip, rehabilitation of pits and buttresses, cleaning and replacement of signs, preservation of defences, and maintenance of bridges.

Additionally, at least twice a year and whenever there are emergency climatic situations, at least the cleaning of sewers and gutters must be carried out.

A homogeneous tariff was established for each of the eight sections of Route 5. Concessionaires of the sections with greater demand made a payment to the State to win the bidding process. Payments collected by the State were enough to finance the sections with lower projected traffic with subsidies. The State was able to collect approximately US $\$ 212.8$ million as payment to the state 
paid by the concessionaires, and at the same time subsidize some sections of Route 5 for a total of US\$36.7 million.

On the other hand, the cross-subsidies for the future self-financing scheme consists of projects that, in their first concession, received state contributions. However, given that demand grows over time, in the second or third bids, they will receive fewer state contributions and/or increase their investments (Friedmann and Hinojosa 1995) [12]. This was the case of the PPP airports projects in Punta Arenas and Concepción.

The Nuevo Pudahuel consortium won the second concession of the Santiago Airport which offered $77.56 \%$ of total concession revenues to the State. In other words, the concessionaire will be operating with $22.44 \%$ of the total revenues collected annually during the concession period. It should be noted that the minimum established by the State was $60 \%$. For the year 2018, the total income was approximately US $\$ 256$ million, of which US\$198.7 million was delivered to the State. These revenues received by the State will then allow financing the regional airports of the network, either with investments to expand existing regional airport infrastructure or with investments in new airport infrastructure and aeronautical security equipment.

DGC has shown its ability to tender for all types of self-financed and co-financed projects, and a wide variety of infrastructure with different types and levels of risk, particularly demand risks (Vassallo, 2006) [13].

\section{Governance of the Chilean Infrastructure Fund (CIF)}

In March 2018, Law 21,082 was enacted, creating the Chilean Infrastructure Fund (CIF) [14]. The CIF was created by the Treasury with a 99\% share of equity, and by Corporación de Fomento de la Producción (CORFO) (Corporation for the Promotion of Production) with 1\%. The shareholders of the CIF are the Chilean Ministry of the Treasury, the Ministry of Public Works, and CORFO. CORFO is an agency of the Chilean Government, under the Chilean Ministry of Economics, in charge of supporting entrepreneurship, innovation, and competitiveness, along with strengthening human capital and technology capabilities.

CORFO's management and administration is led by a board of directors which is chaired by the Minister of the Economy. The board is made up of the Ministers of Finance, Agriculture, Social Development, and Foreign Relations, a representative of the President of the Republic, and an Executive Vice President.

The CIF is managed by a board of directors made up of five members, two of whom are appointed by the President of Chile for a four-year term each. The Minister of Public Works submits a list of five potential members and the President of the Republic selects two of them. The other three members are recommended by the Consejo de Alta Dirección Pública ("Consejo") and appointed by the President of Chile for a five-year term each. The Consejo submits a shortlist for each position consisting of experts with academic prestige, experience, and knowledge in the thematic areas of the CIF. The Ministers of Public Works and Finance design the professional profile of each position and the Council relies on private executive search companies to search for and select candidates. Directors may be selected for future terms to prevent stagnation. CIF policy also regulates conflicts of interest.

In accordance with Article 4 of Law 21,082, the CIF may: (i) finance or invest in infrastructure projects, directly or through third parties, (ii) prepare and carry out the necessary studies to build, expand, repair, preserve, operate, and carry out through a bidding mechanism under the Chilean Public Works Concessions Law, (iii) spend or make investments of a physical or financial nature for new projects, (iv) issue financial debt instruments and guarantee instruments, and (v) incorporate subsidiary or affiliate corporations to fulfill its purpose.

The CIF must be focused on the financial sustainability of its project portfolio and generating profits during each fiscal year. 
On the other hand, the equity of the CIF is made up of the initial capital allocated by the Treasury and CORFO, with the contribution of national state-owned assets for public use, which must be financially certified or validated.

The CIF may grant concessions through the public bidding mechanism and MOP's concessions law. Concessions will have a maximum term of 50 years. The CIF shall take care of maintaining or increasing its economic value. Once the concession ends, the CIF may re-tender the asset under a variety of agreements such as maintenance or ones which alter the size and scope of the asset, as best determined by the owners of the infrastructure, MOP, DGAC, or another public agency.

The CIF will create a virtuous circle that will ensure the infrastructure maintenance in each concession contract and therefore will extend the lifespan of the assets making infrastructure more sustainable.

\section{Creation of Public Wealth and Public Value}

This section distinguishes between the creation of public wealth and public value with the purpose of using those two concepts throughout this research in order to determine if the new Chilean Infrastructure Fund (CIF) has the potential to create them.

\subsection{Public Wealth}

The public wealth of a country includes all public assets owned by the State. However, only a fraction of these total assets generates income, for example, State financial institutions, public companies, infrastructure concessions, and public-private partnerships that generate revenues from the users.

Public wealth creation is important because it could be an effective way to generate fiscal savings, tax reductions, and economic growth. According to Detter and Fölster (2015), countries have public wealth that is greater than their gross debt and the value of global public assets, which is approximately equal to the value of the world gross domestic product [15]. Therefore, increasing the value of public assets by $1 \%$ would mean increasing global growth by about $1 \%$. In the case of the United States, taxes could be reduced by $4 \%$ if the return on the federal government's asset portfolio is increased by 1\%. According to Marsh and McLennan Companies (2018), the stock of public capital in the United States reaches US\$11 trillion [16].

A challenge in increasing public wealth is first to know the value of the country's public wealth. Most countries do not have an inventory of public assets or a valuation of public assets. Another difficulty is to have efficient management of public assets in order to create public wealth. Therefore, the challenge for the State is to apply private sector tools that can optimize management such as principles of transparency, proper accounting, and accurate financial statements (Buiter 1983) [17].

It should be noted that Gupta et al. (2011) concluded that public capital in several low-income countries loses about half its value over time due to the lack of efficient management [18].

In order to overcome the aforementioned difficulties and promote the creation of public wealth, some countries have followed strategies such as creating infrastructure concession systems. These may include private involvement in the building, operation, and maintenance of ports, roads, and airports, among others. Additionally, others have created national wealth funds, which manage or administer public assets whose purpose is to maximize the value of the portfolio with techniques such as active management, restructuring, and monetization of assets. Sharma (2017) estimates the value of assets under management by sovereign wealth funds at US $\$ 6.5$ billion and states that sovereign wealth funds are attractive for financing sustainable development because of their intrinsic long-term and large-scale nature [19].

The creation of wealth by public companies and national wealth funds is based on the concept that their managers can make investment decisions that allow them to measure results, improve outcomes, and fulfill the mission of the organization. This ultimately would maximize the value of the organization. The present value of the entity's income should allow investors to pay investments, and all operating costs and financing costs, and generate wealth for investors. 
Value creation is usually the result of a combination of strategies related to business development, operational aspects, and financial management. The latter involves investment and financial decisions. Investments should be thoroughly studied so that once the project is undertaken, it can have a positive return and its profitability should be higher than the weighted average cost of capital. An example of good financial management would be that the company can finance itself with lower debt costs. This would mean that the concessionaire would be creating value while its weighted average cost of capital would be lower.

From a financial flow point of view, asset recycling has a first phase of revenue collection or, as it is called, "funding", and a second phase in which the resources collected are allocated to the financing of new projects, or "financing".

The funding may come from any of the revenue sources generated by the project, which are part of its cash flows, such as toll roads, airport commercial revenue, port tariffs and others, i.e., then, as the sources of financing for a project may be equity or debt, the State may use those resources to invest in new infrastructure projects.

Thus, the State can create value or public wealth, offering the market infrastructure through which it can collect revenue which, in turn, allows for the total or partial financing of new infrastructure. The final tax balance will depend on the financial structure and business model of each existing project, as well as the level of competition for the project award, compared with the amount of state resources required for financing of the new infrastructure.

\subsection{Public Value and Good Governance}

Today, public and private companies have understood that they must make positive contributions to the society and, at the same time, have appropriate financial performance. Value creation has long been accepted in economics and in the field of management as one of the results of private sector performance according to their respective business models. At the same time, economic theory describes the public sector with the role of intervention when there are market failures such as in the case of externalities, public assets, or imperfect information. However, the public administration research field has been working on the study of public value in recent times.

According to Talbot (2006), public value is what the public values most [20]. The public value approach is attributed to Moore (1995), who stated that the purpose of management in the public sector is to create public value just as its purpose in the private sector is to create private value [21]. In other words, through appropriate strategic management, public administrators can increase the value of infrastructure projects for its citizens. This considers public managers administrators of public assets, making decisions to increase public value and seeking to improve value for citizens.

Meynhardt (2019) states that public value has five main factors that make up a public value profile, and provides five questions to guide any public value inquiry about products or services [22]:

- Instrumental and utilitarian: is it useful and profitable?

- Moral and ethical: is it proper?

- Political and social: is it politically acceptable?

- Aesthetician and hedonist: is it a positive experience?

In the field of public administration, infrastructure concessions together with privatizations are part of the new public management (NPM) approach. This approach encourages private sector participation in the public sphere through private investment and management of public infrastructure. It also incorporates processes and procedures related to business principles and private sector management techniques into the public sector, to maximize the creation of public value.

Mazzucato and Ryan-Collins (2019) state that the development of NPM was influenced by welfare economics and the theory of public choice [23]. These influences minimize potential public sector failures and improve public sector efficiency with private sector practices. Public sector interventions in the face of market failures do not necessarily guarantee efficient results. In a context where infrastructure 
concessions and privatizations have been used globally, NPM researchers have raised questions about whether public values such as accountability, transparency, sensitivity, responsibility, and quality are protected or safeguarded in public-private partnership environments such as infrastructure concessions.

The above concern encouraged Reynaers (2014) to respond to whether these public values are preserved or safeguarded, endangered or strengthened, and create public value in contracts for the design, building, financing, maintenance, and operation (DBFMO) of a road, a water purification project, a detention center, and the remodeling of the Ministry of Finance building in the Netherlands [24]. The author concluded that this type of PPP contract safeguards public values. However, Reynaers (2014) mentioned that "while the structure may protect public values, there is no guarantee that it will" [25]. The reason for this is that the structure of the concession and the way in which the government manages the contract will determine whether there is value creation or diminution.

Public value will be created to the extent that the infrastructure fund can carry out its activities under elements that promote good governance. It is important then to understand what good governance is all about.

The Organizacion Latinoamericana y del Caribe de Entidades Fiscalizadoras Superiores (OLACEFS) (2015), states that the concept and principles of good governance defined by the World Bank are essentially the combination of transparent and accountable institutions, strong skills and competences, and a fundamental willingness to do what is right [26]. Those are the elements that enable a government to provide services efficiently. Good governance consists of an efficient public service, a judicial system that is reliable, and an administration that is accountable to the public. The principles are: public sector management, accountability, legal framework for development, transparency, and access to information.

On the other hand, the United Nations (2008) states that the objectives of good governance in PPP's are [27]:

- fair and transparent bidding processes,

- achieving value for money,

- improvement in essential public services, especially for citizens with greater needs,

- $\quad$ appropriate training for professionals about PPPs

- fair incentives for all parties and fair returns for risk takers, combined with the achievement of commercial success

- $\quad$ sensible negotiation of disputes that ensures the continuation of services and avoids project collapse and public losses, and

- $\quad$ improvement in the security of services provided through PPPs.

\section{Methodology}

The research has a qualitative and quantitative approach. The qualitative approach is suitable for analyzing a new institution, with new roles and objectives in Chilean public administration, and where there is no previous research on this topic. The quantitative approach uses financial valuation methods.

\subsection{Qualitative Approach}

The qualitative approach used in this paper employed the following information sources: (i) literature review papers; (ii) government provisions such as the regulations of the Chilean concession system, the law creating the CIF, the bidding terms of PPP projects, awarding decrees, and bid results of MOP; (iii) news from the media; and (iv) interviews with PPP experts in Chile using the technique of unstructured interviews (Zhang and Wildemuth, 2017) [28].

In this type of interview, the advantage is that no interview guidelines are followed and the conversation progresses freely. The interviewee can comment on his or her opinions on the topic related to his or her field of interest or add relevant information, taking the conversation deeper. 
Additionally, this type of interview allows the interviewer to understand relationships between variables that may not have been considered beforehand.

Some limitations of the unstructured interview technique mentioned by Dana et al. (2013) are the existence of cognitive biases and the potential decrease of accuracy in their experimental studies comparing the statements of the people without and with an interview [29]. In the area of personnel selection, Kausel et al. (2016) generated evidence suggesting that overconfidence as a bias existing in an unstructured interview can have lower reliability in comparison with structured interviews [30]. Blouin et al. (2011) compare the reliability of structured and unstructured interviews for the admission process of a residency program [31].

Corbin and Morse (2003) highlight that unstructured interview techniques "provide participants considerable control over the interview process", which together with the flexibility implicit on it, is important for our research given the fact that the stakeholders interviewed are senior professionals experts in the area of PPP [32]. For this reason, we talked openly with them about the best practices, strengths, and weaknesses of the CIF.

Flexibility is important in the method because the different characteristics of each stakeholder (interests, understanding of the ideas, etc.) required adapting the interview to focus on the specific points where the interviewed stakeholder could add her/his greatest value.

At the time of the interviews, the characteristics of the newly created CIF were briefly presented as most of the interviewees were already aware of the details of the creation of the CIF. Therefore, they had formed opinions about it.

We interviewed ten PPP experts in Chile. Eighty percent of the experts have worked in the government unit (DGC-MOP) at any time in their careers. Seventy percent of the experts have around 30 years of work experience, the average being 28.5 years of experience. At the time the interview was conducted, six of them worked in the private sector as a consultant or concessionaires, two of them in the academy, one of them in the public sector, and one of them in a multilateral agency. Their specific positions are shown in the Table 1 below.

Table 1. Experts Interviewed.

\begin{tabular}{cc}
\hline Number of Experts & Position \\
\hline 1 & Former DGC-MOP. Infrastructure Consultant Company. \\
2 & Former DGC-MOP. PPP Consultant Company \\
3 & Former DGC-MOP. Concessionaire Company \\
4 & Former DGC-MOP. PPP Consultant Company \\
5 & Expert DGC-MOP \\
6 & Former DGC-MOP. PPP Consultant \\
7 & Former DGC-MOP. University Professor \\
8 & PPP Infrastructure Expert. University Professor \\
9 & Former DGC-MOP. Concessionaire Company \\
10 & Infrastructure Expert. Multilateral Agency Consultant \\
\hline
\end{tabular}

Source: Author's interviews. Abbreviations: Chilean Concession Department, Ministry of Public Works (DGC-MOP); public-private partnership (PPP).

Two years after the publication of the law which created the CIF, its Board of Directors was established. However, the five-year business plan had not been officially known. Meanwhile, MOP's DGC continues to make progress on both new and existing infrastructure projects that require new tenders.

The questions to be answered in this study are the following:

- What are the strengths and weaknesses of the creation of the CIF and will it create public value for the country?

- What would be some of the recommendations for the CIF to achieve good governance in its implementation? 
The questions allowed inquiries into whether the CIF, with its current characteristics and inherent strengths that outweigh its weaknesses, will be able to create public value and wealth. The questions also allow us to focus the discussion on the potential dilemma between the fund's power and the participation of an investor/financier involved in a particular project. The dilemma arises out of the MOP's DCG nature of being an efficient body responsible for bids which complements and improves its activities and those of an investor/financier involved in the management of the project and its overall credit health. The investor/financier can be very influential considering that the concession industry has existed for almost three decades in Chile and the concessionaires have access to credit with local and international banks and certain possibilities of issuing instruments such as bonds.

As the DGC has been working properly, it will be necessary to study the added value generated by the CIF which would apparently replicate some of the roles currently performed by the DGC.

The second question allows us to discover some elements to recommend to the CIF in order to achieve good governance and identify difficulties for appropriate implementation. An example of such recommendations is the case regarding the possibility of receiving proposals from private initiatives, and the implementation of a regulatory body for the Chilean concession system.

Once the interviews were transcribed, we used a coding technique, creating labeling/categories for words or short phrases and linking them to the research questions related to the strengths and weaknesses of the Chilean Infrastructure Fund (CIF), its potential for public value creation and recommendations to achieve good governance. We examined and interpreted the qualitative data and categorized the answers on the basis of our knowledge and experience in PPPs. More details on coding technique can be found in Gibbs (2007) and Saldaña (2013) [33,34].

\subsection{Quantitative Approach}

The quantitative approach applies financial methodologies, such as discounted cash flows and real options, to estimate the economic value of the new CIF. Traditional methodologies such as discounted cash flows have two phases as proposed by Nogueira and Gómes (2013); a period of high predictability from the beginning of the project and a period with high volatility and uncertainty that has to be considered to determine the residual value [35]. There is value creation to the extent that the rate of return on investment is higher than the weighted average cost of capital. The purpose of the discounted cash flow method is to determine market value by estimating the future net cash flows from the project and calculating the present value using a discount rate.

Schwartz (2013) states that the real option approach is an extension of the financial options theory applied to real or non-financial assets [36]. As is the case of infrastructure concession projects, it allows for the inclusion of flexibility in such assessments. The methodology of real options that includes volatility within their valuation variables, such as that of Black and Scholes (1973), is a contribution to the valuation of residual values [37].

Myers (1977) proposed the use of the financial option for the valuation of company assets or project evaluation [38]. The financial option is an instrument which suggests that a company may have the right, but not the obligation to buy or sell assets, to make or not make investments, or to carry out or not carry out projects. Subsequently, Trigeorgis (1993) suggests that the flexibility of the real options could be found in options to defer, to paralyze investments, to abandon, to change the scales of operations, to expand, to interact, and to change the business [39].

Real option valuation methodologies compare the value of having the possibility of waiting to make a decision and the value of not having that possibility, taking into account the probabilities associated with each of them. Thus, a very important concept is that real options allow for the value of flexibility in investment decision-making environments, which under traditional project evaluation methodologies through net present value or cash flow discounts are not possible to capture as stated by Trigeorgis and Manson (1987) [40].

The relationship between financial options and real options is made possible by the work of Black and Scholes (1973) [37]. They created a methodology for valuing European financial options that has 
subsequently been applied to the valuation of real options. The methodology has also been formalized in the work of Merton (1973 and 1974) [41,42], and Mason and Merton (1985) [43].

Martins et al. [44] (2013), show applications of real options to infrastructure, highlighting that investment analysis techniques have improved. The applications include the flexibility and uncertainty present in infrastructure projects in variables such as demand, capital costs, and construction costs. These variables are not captured or included in discounted cash flow models. Real options techniques have also been applied to public-private infrastructure concessions or partnerships. Carbonara et al. (2013) present a set of real option strategies for each category of risks identified in concession projects [45].

In the Black-Scholes Merton (BSM) model, considering a call option, the value of the company's equity at maturity of the debt is:

$$
E=\operatorname{Max}\left(V_{T}-D, 0\right)
$$

where:

$E=$ equity value

$V_{T}=$ value of assets at maturity $\mathrm{T}$

$D=$ nominal value of zero bond

Thus, the development of BSM would look like this:

$$
\begin{gathered}
E=V_{0} * N(d 1)-D * e^{-r f T} * N(d 2) \\
d 1=\frac{\ln \left(\frac{V o}{D}\right)+\left(r_{f}+\frac{\sigma_{v}{ }^{2}}{2}\right) T}{\sigma_{v \sqrt{T}}} \\
d 2=\frac{\ln \left(\frac{V o}{D}\right)+\left(r_{f}-\frac{\sigma_{v}{ }^{2}}{2}\right) T}{\sigma_{v \sqrt{T}}}
\end{gathered}
$$

where:

$E=$ equity value

$V_{0}=$ value of assets

$r_{f}=$ risk-free interest rate

$D=$ value of the debt

$\sigma_{v}=$ volatility of asset returns

$T=$ time to maturity of the debt

The description of the methodology used is found in González and Hinojosa (2016) [46]. They state that "the CIF will receive the rights to the residual values of a group of road concessions currently awarded to the private sector and of future concessions to be awarded. For example, the residual value of a concession that expires in period $\mathrm{N}$ and that is part of the assets of the Infrastructure Fund is RV. This value will depend on the evolution of demand in the future. In the case of a road concession, this will depend on the volume of vehicle traffic on the road and the value of tolls. Thus, the CIF has the right to receive a residual value RV in the period N. For that value to materialize, in period $\mathrm{N}-1$, the concession must be re-tendered by the government (or by the CIF) for a period at least equal to period N, and so on."

González and Hinojosa (2016) propose the idea that the CIF has the option to receive from the state at a price equal to zero and a residual value equal to RV in year $\mathrm{N}$, that is, the CIF will own a call option of the RV at year N [46]. This is a conceptual interpretation that allows the use of the option mechanism to value the CIF. As a public company, the CIF receives the entitled assets for free. The CIF has the right, but not the obligation (option) to receive infrastructure assets, the value of which is the asset's residual value. 
The way the law was drafted and the CIF created was as if the CIF had purchased call options over infrastructure assets at a price equal to zero. The CIF should not pay any money to the government for this transfer of assets, which could be kilometers of roads transferred to the public company.

It should be noted that the government is not obliged to transfer the assets to the CIF, but once the set of assets to be transferred to the CIF has been defined, the CIF receives them at no fee.

Thus, $F C N_{0}$ this represents the net cash flows of the concession in period 0 (when the fund was established). Where RV is the exercise price in period N and using the BSM model, RV is expressed as:

$$
\begin{gathered}
R V=\frac{F C N_{0} \times N_{t}\left(d_{1}\right)}{e^{-r N} \times N_{t}\left(d_{2}\right)} \\
d_{1}=\frac{\ln \left(\frac{F C N_{0}}{R V}\right)+\left(r+\frac{1}{2} \sigma^{2}\right) \times(N-t)}{\sigma \times \sqrt{N-t}} \\
d_{2}=d_{1}-\sigma \times \sqrt{N-t}
\end{gathered}
$$

where,

$\sigma$ : volatility of net cash flows

$r$ : risk-free rate

$N($.$) : normal accumulated distribution evaluated in d 1$ and $d 2$

$R V$ : residual value

\section{Results and Discussion}

6.1. What Are the Strengths and Weaknesses/Challenges of Creating the CIF? Will It Create Public Value for the Country?

Considering the literature review, the information about the Chilean concession system and the CIF, the experience of the authors, and the interviews with PPP experts in Chile, the strengths and weaknesses have been ordered by importance.

\subsubsection{Identification of Strengths}

The strengths identified are the following: (i) creation of public wealth, (ii) improvement of infrastructure investment planning, (iii) ability to mitigate contract renegotiation, (iv) agility in the management system, (v) possibility of issuing debt instruments, and (vi) protection of user payment.

- Creation of Public Wealth. The payments that the new concessionaires would make to the CIF for the concession projects that finalize their contracts would be the main source of revenue for the CIF. In the new bidding processes, it is expected that the CIF's projects will be self-sustaining and that the preferred bidding mechanism would be the largest payment to the CIF for the existing infrastructure. The application of the least present value of revenue bidding mechanism (LPVR) with a fixed value of payment to the CIF for existing infrastructure would maximize benefits for the CIF and mitigate the risks of renegotiating contracts. The income of the CIF will pay for all of the expenses of the bidding process as well as the subsequent supervision in the construction and operation stage. Any extra income could even be used to subsidize other projects (with prior authorization from the Ministry of Finance and verified social capital benefit). Subsidizing other projects could result in an increase in their residual values over time so that in a second or third tender, either the subsidies are minimal or the project becomes self-sustaining. The revenue or profits of the CIF become part of its assets and are not integrated into the general revenue of the nation.

- Improvement of Infrastructure Investment Planning. One of the weaknesses of the Chilean infrastructure system, mentioned by the OECD (2017) and confirmed by some of the interviewees, is the lack of adequate planning for investment in medium- and long-term infrastructure [47]. 
The CIF will improve planning for the concession projects included in the CIF's portfolio since it has the obligation to carry it out through the design of a five-year business plan. The business plan will be updated annually and presented for approval to the shareholders' meeting made up of the Ministry of Finance, Ministry of Public Works, and the Production Promotion Corporation (CORFO). According to the law, the plan will include the following points: The objectives and goals of profitability of the company and the investment and development plans, the need for indebtedness, the program of disposition of assets and non-essential business units, the policy of transfers or capitalization of profits, if any, the association and expansion plans of the company, tax transfer requirements, if necessary, and the infrastructure projects to be developed, indicating the modality and the public bidding procedure to be used and the schedule of the calls for bids for the granting of new concessions.

- Ability to Mitigate Contract Renegotiation. Contract renegotiation is an issue faced by many public-private partnership systems internationally because contracts are complex and cannot predict and manage all eventualities that may arise in a long-term relationship between the State and the concessionaire. Engel et al. (2014) indicate that in concessions in Chile a total of US \$ 2900 million was renegotiated between 1993 and 2006, corresponding to 34\% of total investments [48]. The CIF will operate as an autonomous public company whose objective is to be self-sustaining annually. In other words, the CIF must maximize the value of each one of the projects it participates in. The CIF will have incentives to mitigate or reduce the number of renegotiating contracts assuming that it will be able to improve planning, feasibility study designs, and bidding rules. The incentives are driven by the potential problems of renegotiating contracts whose costs would eventually have to be covered with resources from the CIF.

- Agility in the Management System. The CIF, as a public company with private incentives, would have the advantage of being able to streamline ministerial bureaucratic procedures. Therefore, it would be expected that some of the deadlines involved in project planning until the call for bids and project awards could be reduced compared to a normal process carried out entirely by the DGC. The CIF will use the MOP concessions law and regulations used by the DGC for its tenders. In the event that this legal regulation is not used, it must always carry out a public tender for the selection of the concessionaire. The incentives for benefits maximization and financial sustainability of the CIF could create a more agile organizational culture, which will also be reflected in the processes of hiring and managing human resources. The CIF will be able to hire its human resources, assume the responsibilities of the cycle of concession projects, and take advantage of the external knowledge of advisors and investment banks to support the planning, bidding, construction, and operation stages.

- Possibility of Issuing Debt Instruments. The CIF could issue debt financial instruments, which would allow it to have the resources to advance in very long-term projects or those with financial resources needs. This could be an advantage to the extent that the CIF has a risk classification that allows borrowing at relatively low interest rates.

- Protection of user payment. The CIF protects the concept "the one who uses pays" because the main source of income of the self-sustaining concession business is the fee for the service, and it mitigates the risk of political interventions on the pricing schemes established for each concession business.

\subsubsection{Identification of Weaknesses/Challenges}

However, like any public policy initiative, some weaknesses or challenges regarding the fund have been identified. They have been ordered by importance and are the following: (i) multiplicity of attributions, (ii) PPPs does not require guarantees, (iii) conflict between CIF objectives and public interest, (iv) short term coordination with DGC and ministries, (v) mechanism for project transfer to the CIF, (iv) social infrastructure projects would not necessarily be priority of the CIF, and (vii) determination of tariffs. 
- Multiplicity of Attributions. The multiplicity of powers granted by the law to the CIF is identified as a potential weakness since it must allocate resources to all activities, however, only some of them would bring value added. Thus, the CIF should focus its activities on those in which the CIF can add more value and where, as established by law, it must always generate annual profits. For example, in Chile there is depth and liquidity in terms of financing available for infrastructure projects, as the market has demonstrated since the concession system began. Therefore, the CIF's allocation of financing competes with the sources of traditional financing in the market. This moves away specialized institutions in this area that are better prepared to assume credit risk. Additionally, the possibility that the CIF may invest in infrastructure projects (as a public-private venture) may generate regulatory problems, since the State, through the CIF, would be "judge and party" to the project, especially when the concessionaire faces problems of default or needs to renegotiate the contract. In theoretical terms, they are called agency problems, specifically moral hazard problems, which could also generate, in parallel, conflict of interest problems between the regulator and the regulated. At the same time, it contrasts with the subsidiary role that the State has traditionally played in Chile in the sense of participating only in case of failure or insufficiency of market mechanisms.

- Concessions do not require credit guarantees or political risk guarantees. Another attribute that the CIF has is the possibility of awarding guarantees. In this case, as mentioned above, the DGC has already awarded minimum revenue guarantees in concession contracts with the corresponding payment of a premium. The CIF would follow the same scheme that has already been successfully tested and is already known to the concession industry in Chile. It should be noted that Chile is an investment grade country and the Chilean concession industry has not required the issuance of political or credit guarantees, which are also available with multilateral institutions.

- Conflict between CIF Objectives and Public Interest. Gonzalez (2018) mentions that there might be a conflict between the CIF's objectives and public interest, stating that the expansion investments would be carried out after the moment when the expansion is socially profitable [49]. It is explained by the methodological difference between social evaluation and private evaluation. The private evaluation considers revenues and the social evaluation includes social benefits in terms of time savings, cost savings, and others. The CIF has incentives to guide its decisions through private evaluation.

- Short Term Coordination with DGC and Ministries. The initial coordination of the first years of management of the Fund with the DGC and the Ministry of Finance for the transfer of projects, the transfer mechanisms that will be established, and the form of collaboration of the DGC-MOP with the CIF should be defined to mitigate potential friction between institutions and inefficient decision making processes.

- Mechanism for Project Transfer to the CIF. The responsibility for the administration and investment in airport terminals in Chile is held by the Chilean Department of Civil Aeronautics (DGAC). Through a mandate agreement, the DGAC authorizes the MOP to grant airport projects through the concession approach. The same mechanism is used by other public bodies such as the Ministry of Health in the case of hospital concessions. If the public bodies are available to grant the Mandate Agreement to the CIF instead of the MOP and if this method is positive, the mechanism should be used. Additionally, it must be determined whether these types of projects enter the final portfolio of the CIF or will only be "a loan" from said organizations for a period of time. In the alternative, they may not be included in the CIF's portfolio since the management of said infrastructure facilities correspond to each public ministry or public company.

- Social infrastructure projects would not necessarily be priority of the CIF. It is to be expected that the CIF will specialize, using its resources, in a portfolio of self-sustaining projects at the expense of social projects or that require co-financing, such as hospitals and others that require state subsidies. The CIF would then have a project portfolio made up largely of self-sustaining projects and with a smaller share of projects with co-financing from the CIF that would become self-sustaining 
in new future tenders as demand for these projects increases. The DGC would then focus its work on new projects (to be tendered for the first time) or old ones (which have been previously tendered) but which have not been of interest to the CIF, either because they are not self-sustaining or because the subsidy requirement is very high compared to the residual value it would have for a subsequent tender. However, the CIF's project portfolio could include co-financed projects in the event that the State allocates fiscal contributions to financially support projects that the CIF may propose and that have due social returns.

- Determination of tariffs. An issue that is not clear in the Law is which body determines the concession tariffs and with what criteria or methodologies they will be established. The CIF could bid using MOP concession legal regulations or another mechanism. So, given its mandate for financial self-sustainability, it would not have incentives to transfer potential benefits to a general fund, in the event that, for example, rate reductions are possible.

\subsubsection{Creation of Public Value}

There was a consensus among the experts interviewed that the CIF will create public value for the country. Based on the opinions, an attempt has been made to follow Meynhardt (2019), verifying that the five main factors that make up a public value profile are met [22]. In this regard:

- The CIF is useful because it works as an asset recycling mechanism, ensuring that the resources from the concessions can continue to be invested in the sector, meeting the citizens' need for permanent quality infrastructure, and where both new investments and maintenance interventions allow reaching standards and performance indicators determined by the authority.

- The CIF will be profitable because its purpose is to maximize its value. This will be achieved both by the current trust in the concession industry in Chile, and by the service that the concession works currently provide to users. The CIF should ensure that financial resources are well allocated and contribute to the growth of the society, generating value for the whole country.

- The CIF will have an ethical management/leadership, mainly because its executives are chosen competitively through transparent bodies. The same law that created the CIF has several restrictions and penalties for executives who do not comply with the established regulations.

- The CIF will be politically acceptable because, as it is made up, it will remain relatively dependent on the government in power, but with the autonomy provided by the clear and objective fulfillment of its mission. A technical and political balance is expected in its implementation.

- The CIF will be a positive experience since it has the opportunity for the users of its infrastructure to observe a change in the public service in terms of quality, travel time, safety, and other powers specific to each infrastructure.

Our finding claiming that the CIF creates public value is consistent with Moore (1995) which establishes that governments should focus their work towards the achievement of results, and also with Mazzucato and Ryan-Collins (2019) who propose advances for a theory of collective public value creation, where public value is created by the public sector by promoting markets, like the PPP market, to achieve public goals through an effective interaction and collaboration with the private sector [21,23]. CIF creation of value is also in line with the framework to analyze the creation of public value according to the public policy principles suggested by Kattel et al. (2018) [50].

\subsection{Good Governance Will Require the Creation of a Regulatory Body for the Chilean Concession System}

Harrison et al. (2013) identify six roles in an institutional design process of a concession system [51]. They are: responsible for the bidding process, concession contract manager, concession contract supervisor to ensure performance and quality of service, regulator to set concession tariffs, planner and coordinator with other sectors of the economy, and responsible for fiscal sustainability.

At present, the DGC plays most of the above-mentioned roles, except for the accountability of the Chilean Ministry of Finance. With the fund operating, all of these roles will be the responsibility 
of the CIF. However, as the Chilean Ministry of Finance is a shareholder of the CIF, it will always be monitoring the performance of the CIF and its financial resources.

Tariff regulation may result in a potential conflict of interest with the CIF. Due to its incentive of financial sustainability, it can be opposed to social welfare motivations. It would be interesting, then, to propose the creation of an independent regulator that could have, not only the objective of regulating tariffs, but also supervise the performance of the concession services.

This regulator could support these roles for concessions tendered through the DGC and the CIF. Examples of regulatory institutions in concessions in Latin America are OSITRAN (Supervisory Body for Investment in Public Transport Infrastructure) in Peru and the recently created OFAPP (Public-Private Partnerships Inspection Body) in El Salvador. An independent regulator in Chile would be able to focus on establishing a set of indicators to measure the service performance of the concessions, establish tariffs for monopoly services, and disseminate the fulfillment of the obligations of the concessionaire.

The creation of a regulatory body for PPPs in Chile is not a new proposal. In fact, authors like Engel et al. (1997) have already suggested that possibility in the past, but not in the context of a new CIF [52]. At the global level, Guasch (2004) proposed the creation of this type of institution in a context of good governance of PPPs [53].

\subsection{Chilean Infrastructure Fund (CIF) Will Create Public Wealth}

This section applies the quantitative methodology in order to evaluate the CIF's capacity to create public wealth. The CIF has the ability to create an inventory of the projects under its management which is the first step in creating public wealth. The CIF also creates a virtuous circle, receiving payments for the existing infrastructure, and promoting new and better investments in infrastructure.

The study includes all the concessions on Route 5 in Chile. These are eleven concessions. The four most representative interurban concessions include: Santiago-Viña del Mar Highway, Santiago-San Antonio Highway, Santiago-Colina-Los Andes Highway, and North Access to Concepción Highway. The study considers all the necessary variables for valuation, investment costs, operation, and maintenance costs, and income volumes.

The first generation of highway PPP projects in Chile began in the mid-1990s, so the vast majority of contracts are ending in the next five years. Chilean PPP contracts are long-term contracts because the investment amount is high, and they are paid back with tolls that should be affordable to the users according to the cost of living of the country and economic growth among other elements, and with demand risk for concessionaires. Vassallo et al. (2019) highlights the impact of traffic risk for the financial performance of infrastructure concessions in Chile and explains why Chilean PPP road projects have long terms [54]. The CIF valuation can be easily adapted to shorter-term contracts, depending on the type of projects and the characteristics of the country. Table 2 below provides a summary of the information used for the set of projects.

A period between 2020 to 2055 is considered for the modeling. It is important to mention that the modeling period for the valuation of the CIF is 35 years, from year 2020 to year 2055. Currently all the PPP projects are under management and operation by different concessionaries in their first concession period. Therefore the term used in the valuation will depend on the remaining contractual period of each concession included in the CIF. It is assumed that as soon as each PPP project finishes it's concession period, they will be transferred to the CIF. For example, projects finishing their first concession period soon (between 2020 to 2025) will have a longer valuation period (this is the case of Los Vilos-La Serena and North Access to Concepcion). On the other hand, projects that have been tendered recently by the MOP (between 2017 and 2019) will have a shorter valuation term (this is the case of Vallenar-Caldera and La Serena-Vallenar). 
Table 2. Concession period and revenues.

\begin{tabular}{cccc}
\hline Concession Name & Concessionaire & $\begin{array}{c}\text { Net Revenue } \\
\text { ThUS\$ }\end{array}$ & Term \\
\hline Talca-Chillán & Maule Route & 2.8 & 30 \\
Vallenar-Caldera & Valles del Desierto & 2.3 & 10 \\
Temuco-Río Bueno & Los Ríos Route & 0.7 & 32 \\
Santiago-Talca and & Maipo Route & 5.0 & 30 \\
Santiago South Access & Aconcagua Highway & 47.9 & 32 \\
Santiago-Los Vilos & Los Lagos & 24.2 & 32 \\
Río Bueno-Puerto Montt & Canal Route & 8.8 & 5 \\
Puerto Montt-Pargua & Del Elqui & 14.8 & 33 \\
Los Vilos-La Serena & Algarrobo Route & 31.5 & 8 \\
La Serena-Vallenar & Araucanía Route & 1.0 & 30 \\
Collipulli-Temuco & Bosque Route & 1.0 & 30 \\
Chillán-Collipulli & Los Libertadores & 12 & 29 \\
Santiago-Colina-Los & Sol Highway & 62.6 & 34 \\
Andes 57 & Pacífico Routes & 83.1 & 31 \\
Santiago-San Antonio 78 & Itata Highway & 14.1 & 32 \\
Santiago-Viña del Mar 68 & & & \\
North Access to & Concepción & Sialstemts &
\end{tabular}

Source: MOP and financial statements of concessionaires.

As a base case, net income is assumed to grow at a rate of 3\%, and the weighted average cost of capital rate is considered to be $6 \%$ for purposes of conventional cash flow estimates. Additionally, it is assumed that the current concession tariff structures are maintained for new bids on the same projects.

Using the discounted cash flow methodology and considering the 15 road concessions included in this document, the CIF would reach US\$6591 million.

Now, using the real option methodology and clearing the residual value in order to be able to estimate by simulation each of the residual values for the concessions included in the Table 2 of this study:

$$
C=F C N_{0} \times N_{t}\left(d_{1}\right)-V R \times e^{-r N} \times N_{t}\left(d_{2}\right)
$$

Since the initial net present value is known and the price of the call is zero (the state of Chile gives the CIF, at a price equal to zero, the option to receive a residual value equal to RV in year N), then the residual value can be determined by nonlinear optimization using the Generalized Reduced Gradient (GRG) nonlinear solving method according to Lasdon et al. (1974) [55]. This method analyzes the slope of the objective function as the input values of the decision variables change, and determines that an optimal solution has been reached when the partial derivatives are equal to zero.

The CIF with the assumptions described above would be worth US $\$ 8700$ million (volatility $5 \%$ ) or US\$5700 million (volatility $3 \%$ ).

The main differences between the results of the valuations are undoubtedly explained by the different methodology used. In this regard, it should be noted that since there is relative consensus on the discount rate to be used both in the discounted cash flow methodology and in the real option methodology, the valuation of the CIF with real options will depend on the volatility used for their estimate. The valuation of the CIF using real options will also depend on the concession period used for the estimate, increasing its value for concessions with longer periods.

The valuation of the CIF with real option and cash flow methodologies is a first approach to estimate the expected value of the $\mathrm{CIF}$, assuming its focus on interurban road concessions. It should be noted that this valuation will depend on the type of projects ultimately included in the CIF. For example, in the case that urban road concessions are included in the end, the CIF valuation will be much higher since a large part of these projects are already tendered for the first time, so the CIF could be in charge of managing the second tender. 
The valuation of the CIF assets will also depend on the bidding mechanism that the CIF would ultimately establish for each project. The bidding terms will set key aspects for the valuation such as prices, volatility of the income and terms of each PPP projects.

The regulation of the PPP contracts will also impact the value of the CIF. Flexibility could be included, thereby reducing risks related to investment and therefore increasing the value of the CIF. One common regulation is the enlargement of infrastructure triggered by demand. Changing the planning and design stage allows the infrastructure to deal with future uncertainty positively thereby increasing the value calculated through the real option method. Cruz and Marques (2013) address the concept of contract flexibility and how it can be embedded into PPP design [56]. The authors propose a double entry matrix as a model for contract flexibility. Using a hospital case study, the authors discovered that allowing the concessionaire to adapt the infrastructure and services to changing conditions upon new information increases the value of the project.

CIF creation of public wealth is confirmed with positive valuation results under discounted cash flow and real options methodologies. Martins et al. (2013) address the main types of options and valuation mechanisms that can be applied to the infrastructure projects sector [44]. Our paper contributes to the literature by defining a new methodology to evaluate the new Infrastructure Fund (CIF) using real options.

Another extension of our work would be to investigate how the valuation of the CIF can change if the PPP projects of CIF include minimum revenue guarantees (MRGs). For example, Buyukyoran and Gundes (2018) proposed a real-option-based model to identify the optimal upper and lower boundaries of compound minimum revenue guarantees (MRG) and maximum revenue caps (MRC) in order to determine a fair risk allocation structure [57].

\section{Conclusions}

This research has confirmed that the CIF has positive contributions to the country's infrastructure sector. It ensures that the resources from existing concessions remain in the sector and positively contribute to the Chilean concession system, allowing improved planning, institutional framework, governance, and sustainability. This creates public value and increasing public wealth for the country.

It is concluded that the creation of the CIF has important advantages, since it makes it possible to streamline the concession system and mitigate the transaction costs of potential contract renegotiations. The CIF will also ensure financial sustainability because it commits the availability of revenue in the long term to finance infrastructure in the country. In addition, the portfolio of assets within the CIF allows the government to implement guarantees and government support to concessions to improve their financial sustainability.

It is also advisable that the CIF should focus on a set of activities that allow it to add value to the Chilean infrastructure investment system. In this sense, it is difficult to visualize the CIF as a direct financier to concessionaires, since it could be considered a competitor to the banking system or institutional investors that have been participating with the required credit capacity for two decades already in the Chilean concession system. Moreover, as observed in the analysis of financing sources, several private investment funds in infrastructure have even been created in recent times.

Additionally, the authors recommend that the CIF does not participate in the "equity" of projects that are tendered by concession. Doing so will lose the neutral character that it must have to promote competition in the bidding processes that will be its responsibility. In addition, the Chilean concession industry is characterized by its high degree of competition today.

The creation of an independent regulatory body for public-private partnerships that can constrain adverse selection and moral hazard problems is also recommended. The new Chilean regulatory body could determine and substantiate what type of services of each concession has a monopolistic character and set the corresponding tariffs and adjustment mechanisms for the services. Additionally, it could supervise activities in the construction and exploitation stages of the projects. 
Finally, the valuation of the CIF with 15 road projects yields a value of US\$6591 million using discounted flows and between US\$5700 million and US\$8700 million with the real options methodology. These estimations confirm that the CIF has an important value for the concession system in Chile, and the country will be certain that private participation in infrastructure will continue to contribute to Chile's economic progress, now that it is generating wealth that can be accounted for over time.

An interesting future line of research once the CIF becomes operational would be to evaluate its financial management compared to the financial management of the funds of other countries like Australia.

Another future area of research is related to the application of any of the methodologies mentioned in this document regarding the theory of public value or critical success factors to the CIF once it can show future implemented PPP projects.

Author Contributions: P.M. and J.M.V. proposed the research idea; P.M. wrote the original draft and conducted the data analysis; P.M. and J.M.V. made suggestions for revision. All authors have read and agreed to the published version of the manuscript.

Funding: This research received no external funding.

Acknowledgments: We appreciate the support of the Ministry of Public Works and the professionals interviewed for this research. We also gratefully acknowledge all reviewers.

Conflicts of Interest: The authors declare no conflict of interest.

\section{References}

1. MOP. DFL MOP N ${ }^{\circ} 164$, de 1991, Ley de Concesiones de Obras Públicas, Santiago, Chile, 1996. Available online: https://www.bcn.cl/leychile/navegar?idNorma=16121 (accessed on 14 November 2020).

2. Balance de Gestión de la Coordinación de Concesiones de Obras Públicas, Santiago, Chile, 2018. Available online: http://www.concesiones.cl/Documents/2018/Balance\%20de\%20Gesti\%C3\%B3n\%20VE RSION\%20CCOP.pdf (accessed on 14 November 2020).

3. The 2019 Infrascope. The Economist Intelligence Unit. Evaluación del Entorno para las Asociaciones Público-privadas en América Latina y el Caribe: El Infrascopio 2019, Nueva York (NY), 2019. Available online: https://infrascope.eiu.com/wp-content/uploads/2019/04/EIU_2019-IDB-Infrascope-Report _FINAL_ESP.pdf (accessed on 14 November 2020).

4. MOP. Concesiones de Obras Públicas en Chile 20 Años, Santiago, Chile, 2016. Available online: http://www.concesiones.cl/Documents/libro-Concesiones_obras-publicas-chile-20.pdf (accessed on 14 November 2020).

5. Turley, L.; Semple, A. Financing Sustainable Public-Private Partnerships; International Institute for Sustainable Development (IISD): Winnipeg, Manitoba, Canada, 2013; Available online: https://www.iisd.org/system/files /publications/ppp_financing.pdf (accessed on 24 November 2020).

6. Nowacki, C.; Levitt, R.; Monk, A. Innovative Financing and Governance Structures to Solve the Greenfield Infrastructure Gap: A Case Study of New South Wales, Australia; Working Paper; Stanford Global Projects Center: Stanford, CA, USA, 2016.

7. Australian Government. The Treasury. Review of the National Partnership Agreement on Asset Recycling, TSY/AU. January 2019. Commonwealth of Australia 2019. Available online: https:/treasury.gov.au/publicat ion/p2019-t349382 (accessed on 14 November 2020).

8. Casady, C.; Geddes, R. Asset Recycling for Social Infrastructure in the United States. Public Work. Manag. Policy 2020, 25, 1-17. [CrossRef]

9. Gómez-Lobo, A.; Hinojosa, S. Broad Roads in a Thin Country—Infrastructure Concessions in Chile; Working paper, no. WPS 2279; World Bank: Washington, DC, USA, 2000.

10. Vassallo, J.; Sanchez, A. Minimum Income Guarantee in Transportation Infrastructure Concessions in Chile. Transp. Res. Rec. 2006, 1960, 15-22. [CrossRef]

11. CAF- Banco de Desarrollo de América Latina. Afrontando el Reto de Conectar y Mejorar las Ciudades; APP Asociación-Público Privada en América Latina: Bogotá, Colombia, 2018; Available online: https://scioteca.caf.com/handle/123456789/1376 (accessed on 14 November 2020). 
12. Friedmann, J.; Hinojosa, S. Tarificación de la Red Vial Interurbana: Aspectos teóricos y aplicaciones. In Proceedings of the Actas VII Congreso Chileno de Ingeniería de Transporte, Santiago, Chile, 17-20 October 1995.

13. Vassallo, J. Traffic Risk Mitigation in Highway Concession Projects, The Experience of Chile. J. Transp. Econ. Policy 2006, 40, 359-381.

14. MOP (Chilean Ministry of Public Works). Ley Número 21082 Crea Sociedad Anónima del Estado Denominada Fondo de Infraestructura S.A., Santiago, Chile, 2018. Available online: https://www.bcn.cl/leychile/navegar? idNorma $=1116454$ (accessed on 14 November 2020).

15. Detter, D.; Fölster, S. The Public Wealth of Nations. In How Management of Public Assets Can Boost or Bust Economic Growth, 1st ed.; Palgrave Macmillan: New York, NY, USA, 2015; pp. 1-196.

16. Marsh and McLennan Companies (2018), Infrastructure Asset Recycling. Available online: https://www.mm c.com/content/dam/mmc-web/Files/APRC/Infrastructure-Asset\%20Recycling-digital-APRC.pdf (accessed on 14 November 2020).

17. Buiter, W. Measurement of the public sector deficit and its implications for policy evaluation and design. IMF Staff Papers 1983, 30, 306-349. [CrossRef]

18. Gupta, S.; Kangur, A.; Papageorgiou, C.; Wane, A. Efficiency-adjusted Public Capital and Growth; IMF Working Paper WP/11/217; International Monetary Fund: Washington, DC, USA, 2011.

19. Sharma, R. Sovereign Wealth Funds Investment in Sustainable Development Sectors. Global Projects Center-Stanford University. 2017. Available online: https://www.un.org/esa/ffd/high-level-conference-onffd-and-2030-agenda/wp-content/uploads/sites/4/2017/11/Background-Paper_Sovereign-Wealth-Funds. pdf (accessed on 14 November 2020).

20. Talbot, C. Paradoxes and Prospects of 'Public Value'. In Proceedings of the Tenth International Research Symposium on Public Management, Glasgow, Scotland, 10-12 April 2006.

21. Moore, M. Creating Public Value: Strategic Management in Government, 5th ed.; Harvard University Press: Cambridge, MA, USA, 1995; pp. 27-75.

22. Meynhardt, T. Public Value Value Creation in the Eyes of Society. In Public Value Deepening, Enriching, and Broadening the Theory and Practice; Routledge: London, UK, 2019; pp. 5-39.

23. Mazzucato, M.; Ryan-Collins, J. Putting Value Creation back into "Public Value": From Market Fixing to Market Shaping; Working Paper Series (IIPP WP 2019-05); UCL Institute for Innovation and Public Purpose: London, UK, 2019.

24. Reynaers, A. Public Values in Public-Private Partnerships. Public Adm. Rev. 2014, 74, 41-50. [CrossRef]

25. Reynaers, A. It Takes Two to Tangle: Public- private Partnerships and Their Impact on Public Values. Ph.D. Thesis, VU University Amsterdam, Amsterdam, The Netherlands, 2 April 2014.

26. OLACEFS (2015). Fundamentos Conceptuales Sobre la Gobernanza. Available online: https://www.olacefs. com/fundamentos-conceptuales-sobre-la-gobernanza-ctpbg/ (accessed on 14 November 2020).

27. United Nations Economic Commission for Europe (2008). Guidebook on Promoting Good Governance in Public-Private Partnerships; United Nations: New York, NY, USA, 2008; Available online: https: //www.unece.org/cicppp/cecipublications/ceci/2008/guidebook-on-promoting-good-governance-in-public -private-partnerships/guidebook-on-promoting-good-governance-in-public-private-partnerships.html (accessed on 14 November 2011).

28. Zhang, Y.; Wildemuth, B. Unstructured Interview in Applications of Social Research Methods to Questions. Inf. Libr. Sci. 2017, 1, 239-247.

29. Dana, J.; Dawes, R.; Peterson, N. Belief in the unstructured interview: The persistence of an illusion. Judgm. Decis. Mak. 2013, 8, 512-520.

30. Kausel, E.; Culbertson, S.; Madrid, H. Overconfidence in personnel selection: When and why unstructured interview information can hurt hiring decisions. Organ. Behav. Hum. Decis. Process. 2016, 137, $27-44$. [CrossRef]

31. Blouin, D.; Day, A.; Pavlov, A. Comparative reliability of structured versus unstructured interviews in the admission process of a residency program. J. Grad. Med. Educ. 2011, 3, 517-523. [CrossRef]

32. Corbin, J.; Morse, J. The unstructured interactive interview: Issues of reciprocity and risks when dealing with sensitive topics. Qual. Inq. 2003, 9, 335-354. [CrossRef]

33. Gibbs, G. Analysing Qualitative Data, 1st ed.; SAGE Publications Ltd.: London, UK, 2007; pp. $38-55$. 
34. Saldaña, J. The Coding Manual for Qualitative Researchers, 2nd ed.; SAGE Publications Ltd.: London, UK, 2013; pp. 1-242.

35. Nogueira, P.; Gómes, M. The Terminal Value (TV) Performing in Firm Valuation: The Gap of Literature and Research Agenda. J. Mod. Account. Audit. 2013, 9, 1622-1636.

36. Schwartz, E. The Real Options Approach to Valuation: Challenges and Opportunities. J. Econ. 2013, 50, 163-177. [CrossRef]

37. Black, F.; Scholes, M. The pricing of options and corporate liabilities. J. Political Econ. 1973, 81, $637-654$. [CrossRef]

38. Myers, S. Determinants of Corporate Borrowing. J. Financ. Econ. 1977, 5, 147-175. [CrossRef]

39. Trigeorgis, L. Real Options and Interactions with Financial Flexibility. Financ. Manag. 1993, 22, $202-224$. [CrossRef]

40. Trigeorgis, L.; Mason, S. Valuing Managerial Flexibility. Midl. Corp. Financ. J. 1987, 5, 14-21.

41. Merton, R. Theory of Rational Option Pricing. Bell J. Econ. Manag. Sci. 1973, 4, 141-183. [CrossRef]

42. Merton, R. On the pricing of corporate debt: The risk structure of interest rates. J. Financ. 1974, $29,449-470$.

43. Mason, S.; Merton, R. The Role of Contingent Claims Analysis in Corporate Finance. In Recent Advances in Corporate Finance; Altman, E.I., Subrahmanyam, M.G., Eds.; Richard D Irwin Inc.: Homewood, IL, USA, 1985.

44. Martins, J.; Marques, R.; Cruz, C. Real options in Infrastructure: Revisiting the Literature. J. Infrastruct. Syst. 2013, 21, 1-9. [CrossRef]

45. Carbonara, N.; Pellegrino, R.; Vajdic, N. Real Option Theory for Risk Mitigation in Transport PPPs. Built Environ. Proj. Asset Manag. 2013, 3, 199-213.

46. González, A.; Hinojosa, S. Despertando el Capital Dormido: Fundamentos del Fondo de Infraestructura en Chile y Análisis del Proyecto de Ley. Available online: http://www.infraestructurapublica.cl/wp-content/upl oads/2016/11/Fondo-de-Infraestructura-Gonza\%C3\%84\%E2\%80\%94lez-A.-Hinojosa-S.-VF-Julio-2016-.pdf (accessed on 14 November 2020).

47. OECD (2017). Análisis de Gobernanza de Infraestructura: Chile. Brechas y Estándares de Gobernanza de la Infraestructura Pública en Chile. Available online: https://www.oecd.org/gov/brechas-y-estandares-de-gob ernanza-de-la-infraestructura-publica-en-chile-9789264286948-es.htm (accessed on 14 November 2011).

48. Engel, E.; Fisher, R.; Galetovic, A. Renegotiations. In Economía de las Asociaciones Público Privadas; Primera Edición; Fondo de Cultura Económica: Mexico City, Mexico, 2014; pp. 122-124.

49. González, A. Fondo de Infraestructura de Chile. Rev. Estud. De Políticas Públicas 2018, 4, 174-186.

50. Kattel, R.; Mazzucato, M.; Ryan-Collins, J.; Sharpe, S. The Economics of Change: Policy Appraisal for Missions, Market Shaping and Public Purpose; Working Paper Series (IIPP WP 2018-06); UCL Institute for Innovation and Public Purpose: London, UK, 2018.

51. Harrison, R.; Muñoz, R.; Sánchez, J. Institutional Design for Concessions. Netw. Ind. Q. 2013, 15, 3-5.

52. Engel, E.; Fischer, R.; Galetovic, A. La regulación de concesiones viales. Cent. De Estud. Públicos 1997, 193, 1-4.

53. Guasch, J. Granting and Renegotiating Infrastructure Concessions: Doing it Right; WBI Development Studies; World Bank: Washington, DC, USA, 2004.

54. Vassallo, J.; Heras-Molina, J.; Garrido, L.; Gomez, J. Urban toll highway concession system in Santiago, Chile: Lessons learned after 15 years. J. Infrastruct. Syst. 2020, 26, 1-10. [CrossRef]

55. Lasdon, L.; Fox, R.; Ratner, M. Nonlinear optimization using the generalized reduced gradient method. Revue Française d'automatique, Informatique, Recherche Opérationnelle 1974, 8, 73-103. [CrossRef]

56. Cruz, C.; Marques, R. Flexible contracts to cope with uncertainty in public-private partnerships. Int. J. Proj. Manag. 2013, 31, 473-483. [CrossRef]

57. Buyukyoran, F.; Gundes, S. Optimized real options-based approach for government guarantees in PPP toll road projects. Constr. Manag. Econ. 2018, 36, 203-216. [CrossRef]

Publisher's Note: MDPI stays neutral with regard to jurisdictional claims in published maps and institutional affiliations. 